\title{
Effect of Drip Irrigation with Fertigation and Plastic Mulching on Growth and Yield of Coconut (Cocos nucifera L.)
}

\author{
M. Selvamurugan*, V. Navaneetha Pandian and I. Muthuchamy \\ Precision Farming Development Centre, Department of Soil and Water Conservation \\ Engineering, Agricultural Engineering College and Research Institute, Tamil Nadu Agricultural \\ University, Coimbatore 641 003, Tamil Nadu, India \\ *Corresponding author
}

\begin{tabular}{|c|c|}
\hline \multicolumn{2}{|r|}{ A B S T R A C T } \\
\hline & \multirow{6}{*}{$\begin{array}{l}\text { A field experiment was conducted to study the effect of drip irrigation, fertigation and } \\
\text { mulching on coconut (Cocos nucifera L.) var. VHC } 3 \text {. The experiment was laid out in } \\
\text { Randomized Block Design (RBD) with seven treatments and three replications. The } \\
\text { treatments comprised of } 100 \% \text { (T1), } 80 \% \text { (T2) and } 60 \% \text { (T3) recommended dose of } \\
\text { fertilizer with } 100 \text { micron thickness plastic mulch and } 100 \% \text { (T4), } 80 \% \text { (T5) and } 60 \% \text { (T6) } \\
\text { recommended dose of fertilizer without plastic mulch. The control was with conventional } \\
\text { method of irrigation (basin irrigation) without mulch (T7). The recorded data on the } \\
\text { growth and yield of coconut revealed that the plant height, canopy development and other } \\
\text { plant growth parameters were higher in the treatment with } 100 \% \text { recommended dose of } \\
\text { fertilizer ( } 0.50: 0.32: 1.20 \mathrm{~kg} \text { of NPK / tree) with } 100 \text { micron thickness plastic mulch (T1) } \\
\text { when compared to other treatments. The maximum yield attributes viz., spathe length, } \\
\text { number of inflorescence, number of bunches/palm/year and number of nuts/bunch of } \\
127.76 \mathrm{~cm}, 13,13 \text { and } 31 \text {, respectively were recorded in } 100 \% \text { of recommended dose of } \\
\text { drip fertigation with } 100 \text { micron plastic mulching. The lowest spathe length, number of } \\
\text { inflorescence, number of bunches/palm/year and number of nuts/bunch of } 92.16 \mathrm{~cm}, 8,8 \\
\text { and } 12 \text {, respectively were recorded in control treatment without mulch. The number of nuts } \\
\text { per palm, an important yield contributing trait was promising with } 292 \text { nuts/ palm/ year in } \\
100 \% \text { of recommended dose of drip fertigation with } 100 \text { micron plastic mulching (T1) } \\
\text { treatment. Likewise gradual reductions in weed population, superior water use efficiency } \\
\text { and nutrient use efficiency were observed in all the plastic mulch combination treatments } \\
\text { when compared with other treatments without mulch. }\end{array}$} \\
\hline & \\
\hline & \\
\hline Article Info & \\
\hline & \\
\hline & \\
\hline
\end{tabular}

\section{Introduction}

Coconut (Cocos nucifera L.) is a perennial crop grown mainly in the tropics and subtropics of India, the Philippines, Malaysia, Sri Lanka, and Indian Ocean and South Pacific islands. Coconut is a multi-utility palm that plays a significant role in the economy of these countries, including 10 million farming communities in India (Naresh
Kumar et al., 2008). The annual demand for coconut-based products is projected to increase to about 17 billion nuts by 2020 (Naresh Kumar, 2007). Hence, evaluating the effect of precision farming technologies viz., drip irrigation, fertigation and plastic mulching on plant growth and yield of coconut is imperative. 
Coconut palm requires large quantities of water per day for its normal growth and yield. Adequate and assured supply of water throughout the year, either by rainfall or by irrigation or by sub-soil moisture is imperative for the successful cultivation of coconut palms. To improve upon the productivity of coconut under moisture stress conditions a package has to be developed.

Plasticulture techniques such as drip irrigation and plastic film mulch have undoubtedly contributed to increase the productivity of agricultural and horticultural crops in many regions of the world. In India, Drip fertigation cum plastic film mulch in coconut has shown promise for increasing productivity. However, very little research data is available on the performance of coconut palms under drip fertigation cum plastic film mulch. With this in view, the trial has been conducted.

\section{Materials and Methods}

A field experiment was conducted to evaluate the effect of drip fertigation and plastic mulching on plant growth and yield of coconut at Farms of Precision Farming Development Centre, Department of Soil and Water Conservation Engineering, Tamil Nadu Agricultural University, Coimbatore. The soil of the experimental field was categorized as clay loam. The soil was neutral in reaction with low in organic carbon, available nitrogen and phosphorus and medium in available potassium. Normal weather conditions prevailed during the crop growth period. The experiment was laid out in a randomized block design with seven treatments and three replications.

\section{Treatment details}

T1 - 100\% RDF- Drip fertigation with mulch

T2 - 80\% RDF- Drip fertigation with mulch
T3 - 60\% RDF- Drip fertigation with mulch

T4 - 100\% RDF- Drip fertigation without mulch

T5 - 80\% RDF- Drip fertigation without mulch

T6 - 60\% RDF- Drip fertigation without mulch

T7 - Control (conventional method of irrigation and fertilization without mulch)

(RDF- Recommended Dose of Fertilizer)

The pits of $1 \times 1 \times 1$ meter were dug with a spacing of $7.5 \times 7.5 \mathrm{~m}$ and the pits were filled with $50 \mathrm{~kg}$ of FYM, red earth and sand mixed at equal proportions. The treatments were allocated to each pit as per random principle. Thereafter, planting of 10 months old quality seedlings of coconut var. VHC-3 was carried on December, 2004. After planting, 100 micron thickness black plastic mulch was laid as $1.5 \mathrm{~m}$ diameter from the base of the coconut as per the treatment details. All cultural practices including gap filling, weeding, plant protection measures and other cultural practices were done as per the recommendations of Tamil Nadu Agricultural University. The various growth, yield and quality parameters were recorded at appropriate stages.

\section{Crop water requirement}

During experimental periods, the irrigation has been given as per the following details.

First year -16 lit/plant/day

Second year- 32 lit/plant/day

Third year onwards - 72 lit/plant/day

Control - Flood irrigation once in 8 days (Ring basin method) 


\section{Fertigation schedule}

Monthly once fertigation has been given as per the details furnished in Table 1.

\section{Results and Discussion}

\section{Effect of drip fertigation and plastic mulching on coconut}

In this experiment, the various plant growth parameters, yield attributes and yield of coconut were observed from the year 2008-09 to 2012-13 and the results shown that the maximum growth of coconut and nut yield were recorded in drip fertigation at $100 \%$ of recommended fertilizer dose (0.50:0.32:1.20 $\mathrm{kg}$ of $\mathrm{NPK} /$ tree) with plastic mulching compared to other treatments. In entire period of study, trees grown under plastic mulch showed a dramatic increase in trunk height, stem girth and number of leaves over trees grown under no mulch. Among different treatments, $100 \%$ of recommended dose of drip fertigation (0.50:0.32:1.20 kg of NPK / tree) (from $4^{\text {th }}$ year onwards) with 100 micron plastic mulching $\left(\mathrm{T}_{1}\right)$ had registered significantly higher trunk height, stem girth and number of leaves $(6.11 \mathrm{~m}, 145.46 \mathrm{~cm}$ and 31.80 , respectively) and the lower was in conventional method of irrigation and no mulch trees $\left(\mathrm{T}_{7}\right)(4.79 \mathrm{~m}, 106.90 \mathrm{~cm}$ and 23.30, respectively) (Table 2).

Figure 1 shows the root zone temperature $\left({ }^{\circ} \mathrm{C}\right)$ of coconut as influenced by drip fertigation and mulching. In general, plastic mulches increased the root zone (soil) temperature in relation to non-mulch soil and the increase was $0.50-2.30{ }^{\circ} \mathrm{C}$. Data regarding soil temperature under different mulch treatments revealed that plastic mulches increased soil temperature significantly than un-mulched control plots. Suwon and Judah (1985) also reported that soil temperature increased with the use of plastic mulch.

Table.1 Recommended Dose of Fertilizer (RDF) for coconut

\begin{tabular}{cccc}
\hline Age & $\mathrm{N}(\mathrm{g} /$ tree $)$ & $\mathrm{P}_{2} 0_{5}(\mathrm{~g} /$ tree $)$ & $\mathrm{K}_{2} \mathrm{O}(\mathrm{g} /$ tree $)$ \\
\hline First year & 50 & 40 & 135 \\
Second year & 160 & 120 & 405 \\
Third year & 330 & 240 & 810 \\
Fourth year onwards & 500 & 320 & 1200 \\
\hline
\end{tabular}

Table. 2 Height of trunk, trunk girth and number of leaves in coconut as influenced by drip fertigation and plastic mulching

\begin{tabular}{|l|c|c|c|}
\hline \multicolumn{1}{|c|}{ Treatments } & $\begin{array}{c}\text { Height of } \\
\text { trunk }(\mathrm{m})\end{array}$ & $\begin{array}{c}\text { Trunk } \\
\text { girth }(\mathrm{cm})\end{array}$ & $\begin{array}{c}\text { Number of } \\
\text { leaves/tree }\end{array}$ \\
\hline T1 - 100\% RDF- Drip fertigation with mulch & 6.11 & 145.46 & 32 \\
\hline T2 - 80\% RDF- Drip fertigation with mulch & 5.72 & 138.12 & 29 \\
\hline T3 - 60\% RDF- Drip fertigation with mulch & 5.51 & 119.50 & 27 \\
\hline T4 - 100\% RDF- Drip fertigation without mulch & 5.82 & 123.24 & 28 \\
\hline T5 - 80\% RDF- Drip fertigation without mulch & 5.30 & 117.03 & 26 \\
\hline T6 - 60\% RDF- Drip fertigation without mulch & 5.27 & 112.70 & 25 \\
\hline T7 - Control (without mulch) & 4.79 & 106.90 & 23 \\
\hline Sed & 0.40 & 2.98 & 1.24 \\
\hline CD (0.05) & 0.83 & 6.17 & 2.57 \\
\hline
\end{tabular}


Table.3 Number of inflorescence in coconut as influenced by drip fertigation and plastic mulching

\begin{tabular}{|c|c|c|c|c|c|c|}
\hline Treatments & $2008-09$ & $2009-10$ & $2010-11$ & $2011-12$ & $2012-13$ & Pooled Mean \\
\hline T1 - 100\% RDF- Drip fertigation with mulch & 12.00 & 12.00 & 12.00 & 14.00 & 14.00 & 12.80 \\
\hline T2 - 80\% RDF- Drip fertigation with mulch & 11.66 & 12.00 & 12.00 & 13.00 & 13.00 & 12.33 \\
\hline T3 - 60\% RDF- Drip fertigation with mulch & 11.33 & 11.33 & 11.33 & 12.00 & 11.00 & 11.40 \\
\hline T4 - 100\% RDF- Drip fertigation without mulch & 11.33 & 12.00 & 12.00 & 12.00 & 13.00 & 12.07 \\
\hline T5 - 80\% RDF- Drip fertigation without mulch & 11.00 & 11 & 11.33 & 13.00 & 11.00 & 11.47 \\
\hline T6 - 60\% RDF- Drip fertigation without mulch & 10.60 & 10.60 & 10.60 & 11.00 & 10.00 & 10.56 \\
\hline T7 - Control (without mulch) & 0.00 & 9.67 & 9.67 & 10.00 & 9.00 & 7.67 \\
\hline Sed & 0.43 & 0.36 & 0.36 & 0.46 & 0.36 & 0.82 \\
\hline $\mathrm{CD}(0.05)$ & 0.95 & 0.76 & 0.76 & 0.91 & 0.71 & 1.70 \\
\hline
\end{tabular}

Table.4 Number of nuts/ palm/ year in of coconut as influenced by drip fertigation and plastic mulching

\begin{tabular}{|c|c|c|c|c|c|c|}
\hline Treatments & $2008-09$ & $2009-10$ & $2010-11$ & $2011-12$ & $2012-13$ & Pooled Mean \\
\hline T1 - 100\% RDF- Drip fertigation with mulch & 282 & 293 & 302 & 295 & 288 & 292 \\
\hline T2 - 80\% RDF- Drip fertigation with mulch & 272 & 268 & 277 & 270 & 268 & 271 \\
\hline T3 - 60\% RDF- Drip fertigation with mulch & 198 & 210 & 215 & 208 & 205 & 207 \\
\hline T4 - 100\% RDF- Drip fertigation without mulch & 228 & 232 & 237 & 224 & 227 & 230 \\
\hline T5 - 80\% RDF- Drip fertigation without mulch & 190 & 193 & 198 & 196 & 194 & 194 \\
\hline T6 - 60\% RDF- Drip fertigation without mulch & 170 & 173 & 183 & 176 & 172 & 175 \\
\hline T7 - Control (without mulch) & 0 & 121 & 128 & 124 & 126 & 125 \\
\hline Sed & 18.63 & 15.24 & 14.42 & 9.51 & 8.96 & 9.25 \\
\hline $\mathrm{CD}(0.05)$ & 40.59 & 33.19 & 31.42 & 18.65 & 17.56 & 19.09 \\
\hline
\end{tabular}

Table.5 Water Use Efficiency and Fertilizer Use Efficiency in coconut as influenced by drip fertigation and plastic mulching

\begin{tabular}{|c|c|c|c|c|}
\hline Treatments & $\begin{array}{l}\text { Water Use Efficiency } \\
\text { (nuts/ha. } \mathrm{m}^{3} \text { of water) }\end{array}$ & $\begin{array}{c}\text { Nitrogen Use Efficiency } \\
\text { (nuts/ha. kg of N) }\end{array}$ & $\begin{array}{c}\text { Phosphorus Use Efficiency } \\
\text { (nuts/ha. kg of P) }\end{array}$ & $\begin{array}{c}\text { Potassium Use Efficiency } \\
\text { (nuts/ha. kg of K) }\end{array}$ \\
\hline T1 - 100\% RDF- Drip fertigation with mulch & 34 & 584 & 913 & 243 \\
\hline T2 - 80\% RDF- Drip fertigation with mulch & 31 & 678 & 1059 & 282 \\
\hline T3 - 60\% RDF- Drip fertigation with mulch & 24 & 690 & 1078 & 288 \\
\hline T4 - 100\% RDF- Drip fertigation without mulch & 27 & 460 & 719 & 192 \\
\hline T5 - 80\% RDF- Drip fertigation without mulch & 22 & 485 & 758 & 202 \\
\hline T6 - $60 \%$ RDF- Drip fertigation without mulch & 20 & 583 & 911 & 243 \\
\hline T7 - Control (without mulch) & 14 & 250 & 391 & 104 \\
\hline Sed & 0.89 & 48 & 32 & 20 \\
\hline $\mathrm{CD}(0.05)$ & 1.97 & 100 & 71 & 44 \\
\hline
\end{tabular}


Fig.1 Root zone temperature $\left({ }^{\circ} \mathrm{C}\right)$ of coconut as influenced by drip fertigation and plastic mulching

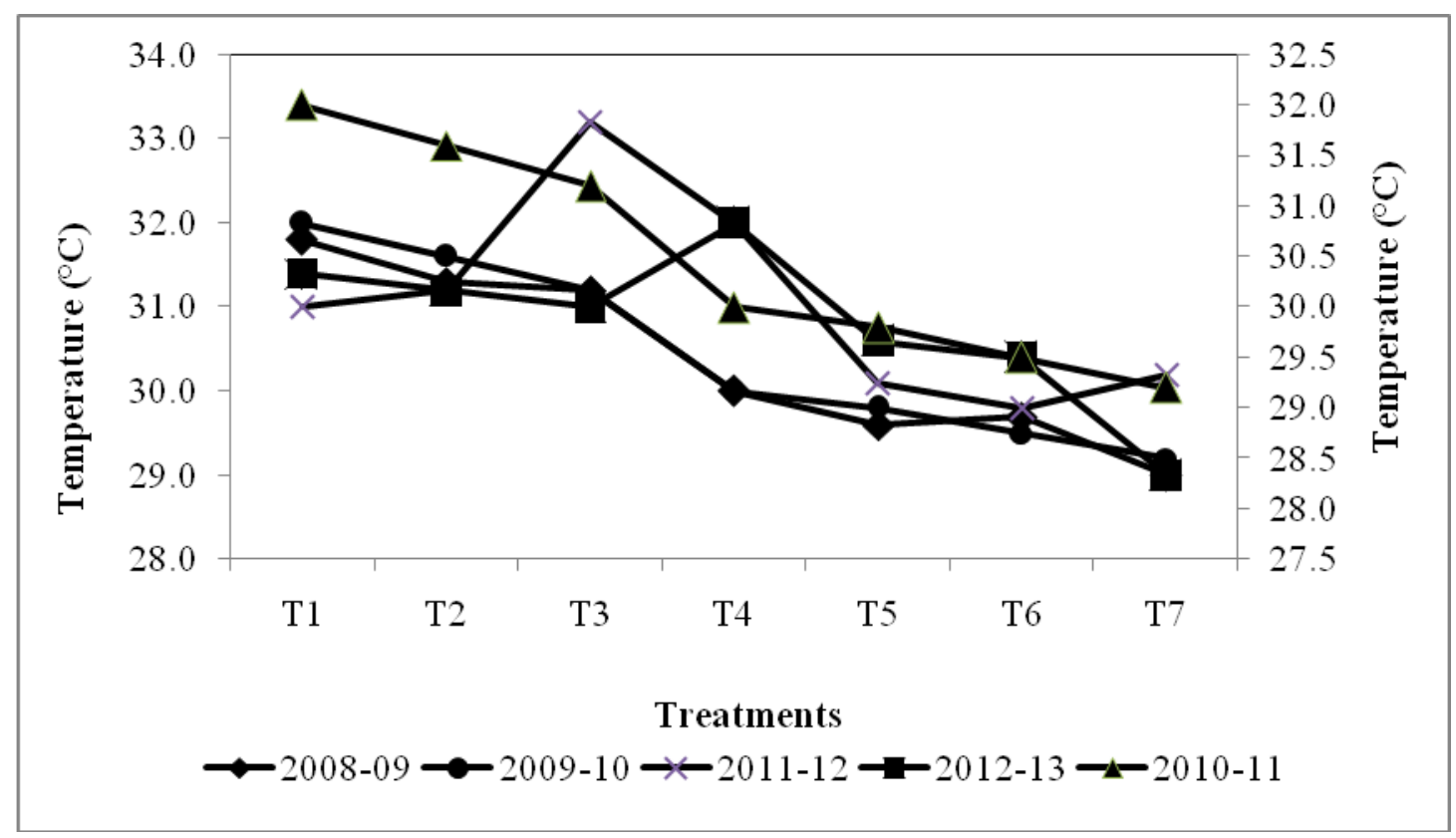

This is because polythene mulches allowed part of the radiation to pass through it but acted as barriers against outgoing thermal radiation (Park et al., 1987). The temperature increase under plastic mulch is due to high soil moisture content, which leads to more heat flux for thermal conductivity (Robock $e t$ al., 2000; Chen and Dudhia 2001). The temperature increase in the Black Plastic Mulch condition might be because the black film absorbed incoming solar radiation and radiated much of this energy as sensible heat to the air (above) and soil (below). This well documented soil temperature rise is often used as an explanation for increased growth of coconut grown under plastic mulch (Davis, 1994 and Qumer et al., 2009).

As per the data shown in Table 3, drip fertigation with plastic mulching stimulated the plant growth and hastened the flowering in coconut. The maximum number of inflorescences per tree was recorded with drip fertigated along with mulched coconut compared to non-mulched and conventional irrigated coconut. The highest number of inflorescences of 12.80 was recorded in drip fertigation at $100 \%$ of recommended dose of fertilizer (0.50:0.32:1.20 kg of NPK/tree) with plastic mulching while the lowest number of inflorescences of 7.67 was recorded in nonmulched and conventional irrigated coconut.

The drip fertigation cum plastic mulching induced growth stimulation was also reflected in yield attributes and yield of coconut. The maximum spathe length and number of nuts/bunch of $127.76 \mathrm{~cm}$ and 31 , respectively were recorded in $100 \%$ of recommended dose of drip fertigation with 100 micron plastic mulching $\left(\mathrm{T}_{1}\right)$. The lowest spathe length and number of nuts/bunch of $92.16 \mathrm{~cm}$ and 12 , respectively were recorded in control treatment without mulch $\left(\mathrm{T}_{7}\right)$. The maximum nuts yield of 292 numbers / palm / year was also recorded in the $100 \%$ of recommended dose of drip fertigation (0.50:0.32:1.20 kg of NPK / tree) along with 100 micron plastic mulching $\left(\mathrm{T}_{1}\right)$ which was higher than conventional method (125 numbers / palm / 
year), by enhancement of 167 nuts per palm / year (Table 4). In coconut palms, the drip fertigation cum plastic mulch increased the root zone (soil) temperature with moisture retention and changed plant microclimate in near the soil region and lowered the temperature of the canopy microclimate and thereby increased the plant growth parameters and yield attributes. Further, drip fertigation cum plastic mulch increased button nut production and nut setting and thus improving the yield.

In general, weed suppression was also higher (57\% in first, $43 \%$ in second and $27 \%$ in third year) in plastic mulched plots compared to unmulched plots. Similarrly, Ibe et al., (2012) obtained better weed control than the hoeweeding method in okra cultivation. The Water and Fertilizer Use Efficiency was also increased in the above recommendation of 100 micron plastic mulching. The highest Water Use Efficiency of 34 nuts/ tree. $\mathrm{m}^{3}$ of water was recorded in $100 \% \mathrm{RDF}$ drip fertigation (0.50:0.32:1.20 kg of NPK/tree) (from $4^{\text {th }}$ Year onwards) with 100 micron plastic mulching (T1) whereas, the lowest Water Use Efficiency of 14 nuts/ tree. $\mathrm{m}^{3}$ of water was registered in Conventional Flood Irrigation without mulch (T7) (Table 5). This result is in line with the findings of Seyfi et al., (2007), which showed that drip irrigation with black plastic mulch markedly decreased the amount of water applied, increased water use efficiency (WUE) and increased crop yield due to increase in number of fruits per plant, fruit weight and fruit thickness.

The result of the present study revealed that the plant growth parameters, yield attributes and nuts yield of coconut were enhanced by the combined effect of drip fertigation at $100 \%$ of recommended dose of fertilizer with plastic mulching over to conventional irrigation without mulch. Hence, the present study recommends the $100 \%$ RDF drip fertigation with 100 micron plastic mulching to maximizing yield in coconut.

\section{Acknowledgement}

The authors wish to express their gratitude to the National Committee in Plasticulture Applications in Horticulture (NCPAH), Government of India, Ministry of Agriculture, New Delhi for providing financial support for this study.

\section{References}

Chen, F. and Dudhia, J. 2001. Coupling an advanced land surfacehydrology model with the Penn State-NCAR MM5 modeling system. Part I: Model implementation and sensitivity. Mon. Wea. Rev. 129: 569-585.

Davis, J. M. 1994. Comparison of mulches for fresh-market basil production. Hort Science 29: 267-268.

Ibe, R. B., Alamu, 0. 0. and Olaniyi, O. W. 2012. Economic analysis of the effect of mulch on weed control and yield of okra (Abelmoschus esculentus L. Moench). Nigerian Journal of Horticultural Science, 17: 80-87.

Naresh Kumar, S. 2007. Climate change effects on growth and productivity of plantation crops with special reference to coconut and black pepper: impact, adaptation and vulnerability and mitigation strategies. ICAR Network Project Final Report, ICAR, New Delhi, India.

Naresh kumar, S., Kasturi bai, K.V., Rajagopal, V. and Aggarwal, P. K. 2008. Simulating coconut growth, development and yield with the InfoCrop-coconut model. Tree Physiology 28: 1049-1058.

Park, S. U., Park, K. Y., Kang, Y. K. and Jong, S. K. 1987. Effect of polythene mulching and tunnel on the growth and yield of 
early produced sweet corn. Res. Rep. Rural Dev. Adm. Crops. 29: 245-250.

Qumer, I., Muhammad, A., Muhammad, R. A., Muhammad A. A. and Riaz, A. 2009. Vegetative and Reproductive evaluation of hot peppers under different plastic mulches in poly/ plastic tunnel. Pak. J. Agri. Sci. 46(2): 113-118.

Robock, A., Vinnikov, K. Y., Srinivasan, G., Entin, J. K., Hollinger, S. E., Speranskaya, N. A., Liu, S. and Namkhai, A. 2000. The Global Soil
Moisture Data Bank, Bull. Am. Meteorol. Soc. 81(6): 1281-1299.

Seyfi, K. and Rashidi, M. 2007. Effect of drip irrigation and plastic mulch on crop yield and yield components of Cantaloupe. Int. J. Agric. Biol. 9(2): 247-249.

Suwon, M. A. and Judah, O. M. 1985. Influence of plastic mulching on growth and yield and soil moisture conservation in plastic house tomatoes. Dirasat, 12: $21-23$.

\section{How to cite this article:}

Selvamurugan, M., V. Navaneetha Pandian and Muthuchamy, I. 2017. Effect of Drip Irrigation with Fertigation and Plastic Mulching on Growth and Yield of Coconut (Cocos nucifera L.). Int.J.Curr.Microbiol.App.Sci. 6(11): 2596-2602. doi: https://doi.org/10.20546/ijcmas.2017.611.304 